\title{
Modifications in Chemical, Physical and Mechanical Properties of Nebbiolo (Vitis vinifera L.) Grape Berries Induced by Mixed Virus Infection
}

\author{
D. Santini ${ }^{1}$, L. Rolle ${ }^{2}$, P. Cascio ${ }^{3}$, F. Mannini ${ }^{*}$
}

(1) Istituto Virologia Vegetale - CNR - UOS Grugliasco, Via L. da Vinci 44, 10095 GRUGLIASCO (TO), Italy

(2) DIVAPRA - Tecnologie Alimentari - Università degli Studi di Torino, Via L. da Vinci 44, 10095 GRUGLIASCO (TO), Italy

(3) Enosis Meraviglia s.r.l., Via per Cuccaro 19, 15043 Fubine (AL), Italy

Submitted for publication: February 2011

Accepted for publication: March 2011

Key words: GFLV, GLRaV-1, GLRaV-3, GVA, berry-skin thickness, anthocyanin extractability

\begin{abstract}
Modifications in grape quality parameters induced by mixed infection with GFLV and GFkV, GLRaV-1 and GVA, and GLRaV-3 and GVA in three Nebbiolo clones were compared against healthy plants of the same clones in two experimental vineyards in Piemonte, northwest Italy. The aim of the study was to evaluate the effect of virus infection on the mechanical properties of the berry skin and the whole berry as assessed by texture analysis tests, and on the amount and quality of berry skin phenols. Differences were observed in grapevine vigour, yield and juice composition, depending on the viral status of the plants. The anthocyanin profile of the vines infected with GFV and GFkV and those infected with GLRaV-1 and GVA showed a lower percentage of the more stable tri-substituted malvidin-3-glucoside and a higher percentage of cyanidin and peonidin-3-glucosides. Texture analysis showed that the viruses may increase berry-skin thickness and reduce phenol extractability. These effects carry practical implications for wine quality.
\end{abstract}

\section{INTRODUCTION}

Viral infections in grapevines cause crop losses in wineproducing regions worldwide. Grapevine leafroll-associated virus 1 and 3 (GLRaV-1 and -3, genus Ampelovirus), Grapevine virus A (GVA, genus Vitivirus), Grapevine fanleaf virus (GFLV, genus Nepovirus), and Grapevine fleck virus (GFkV, genus Maculavirus) are the causal agents of the most common and dangerous grapevine diseases: leafroll, rugose wood, fanleaf and fleck respectively. These viruses produce distinctive symptoms on infected grapevines: colour alteration and downward rolling of leaves (GLRaV-1 and -3); stem grooving (GVA); severe malformation and leaf chrome-yellow discoloration (GFLV); whereas GFkV is latent in Vitis vinifera (Martelli, 1993; Boscia et al., 1995).

Information on the impact of these viruses on cultivar performance is scarce. Studies have reported that infection is often associated with reduced vegetative vigour, yield and grape juice quality, with a decrease in soluble solids and higher titratable acidity (Walter \& Martelli, 1996; Credi \& Babini, 1997; Cabaleiro et al., 1999; Kovacs et al., 2001; Borgo et al., 2003; Mannini, 2003). Other quality parameters altered by viral infection are the amount of aromatic compounds in Muscat grapes (Mannini et al., 2006) and of phenols in red grapes (Guidoni et al., 1997; Mannini et al., 1999). The content of phenols is crucial in red wines because it determines product quality, affecting colour, body and taste (Vidal et al., 2004; Celotti \& Carcereri De Prati, 2005; De Beer et al., 2006).

These pigments are not always easily extracted from skins during winemaking and low extraction can result in a poorly coloured wine (Rolle et al., 2008; Zanoni et al., 2010). In the wines made from Nebbiolo grapes, the lower extractability of phenols from the skin can also reduce the amount of tannins, because they are chiefly concentrated (75 to $85 \%$ ) in this part of berry (Cagnasso et al., 2008).

In general, the extraction of phenols from skins and seeds during maceration-fermentation will depend on the oenological technique (Gómez-Míguez \& Heredia, 2004; Sacchi et al., 2005). However, the chemical composition of the cell wall of the grape skin may affect its mechanical resistance to releasing anthocyanins (Ortega-Regules et al., 2006). Currently, the cellular maturity index or extractability index (EA\%) (Gonzáles-Neves et al., 2010), mechanical properties of the whole berry (springiness, chewiness and gumminess) (Zouid et al., 2010) and skin mechanical characteristics (skin break force and thickness) (Rolle et al., 2009; Rio Segade et al., 2011) are the best parameters for reliably obtaining a direct estimate of phenol compound extractability. Two other factors related directly to resistance 
against splitting, berry rot and plant diseases are berry skin hardness and thickness (Lang \& During, 1990; Gabler et al., 2003).

The aim of this study was to investigate the effects of five common grapevine viruses on the chemical composition, including technological parameters and phenol characteristics, extractability indexes and mechanical properties of the grapes of Nebbiolo, one of the best-known Italian cultivars used for making the big reds of Piedmont, such as Barolo and Barbaresco DOCG wines. Despite the higher value of wines made from Nebbiolo, the cultivar is notoriously difficult for winemaking because of the low amount of extractable anthocyanins from its grapes and because the plant is susceptible to virus infection. Viral diseases are therefore common in commercial vineyards.

\section{MATERIALS AND METHODS}

\section{Grapes, viruses and sampling}

In two experimental vineyards, planted in the Langhe winemaking area (Piedmont, northwest Italy) in 1992, healthy and virus-infected progeny of three clones of Vitis vinifera L. Nebbiolo cv. were established side by side in the rows. Each progeny derived from a single mother vine originally virus-infected or recovered by heat treatment (Guidoni et al., 1997a). All the vines were cane pruned, vertically trained, and grafted on healthy 420 A rootstock. Plant density was about 5000 vines/hectare.

In the first vineyard, healthy vines of Nebbiolo clone CVT 63 were compared to vines of the same clone infected with GFLV and GFkV. Likewise, in a second vineyard, healthy and infected vines of clone CVT 308 (mixed infection with GLRaV-1 and GVA) and healthy and infected vines of clone CVT 415 (mixed infection with GLRaV-3 and GVA) were compared.

The sanitary status of each vine was confirmed by DAS or (DASI)-ELISA performed on dormant cane samples collected in the winter of 2007/2008 and using commercial kits (Agritest, Valenzano, BA, Italy) according to the manufacturer's instructions. Twenty healthy and 20 infected plants were selected for each clone and observations were carried out over the 2008 growing season.

At harvest, the crop parameters (yield, bunch and berry weight) were assessed individually on the 20 selected vines for each combination, as well as the pruning wood weight controlled during the winter. In addition, samples of about 400 berries each were collected from three vines parcels chosen from the 20 vines and replicated three times along the rows to measure juice parameters (reducing sugars, titratable acidity, $\mathrm{pH}$ and organic acids) to determine the phenolic composition and the relative extractability index of the berries. Likewise, samples of about 150 berries each were picked from the same three vines parcels for the texture analysis tests. The berries, with pedicels attached, were picked randomly from both sides of each cluster and quickly delivered to the laboratory in a cool box for analysis.

\section{Chemical analysis \\ Chemicals}

Chemicals were purchased from Sigma (Milan, Italy). Solutions were prepared in deionised water produced with a Purelab Classic system (Elga Labwater, Marlow, UK). Anthocyanin standards (delphinidin-3-O-glucoside chloride, malvidin-3-O-glucoside chloride, peonidin-3-O-glucoside chloride, cyanidin-3-O-glucoside chloride, petunidin chloride), resveratrol and $(+)$-catechin) were supplied by Extrasynthèse (Genay, France).

\section{Technological parameters of ripeness}

The analytical parameters of grape juice (reducing sugars, titratable acidity, $\mathrm{pH}$ ) were estimated using International Organization of Vine and Wine methods (O.I.V., 2008). The contents of tartaric and malic acid were analysed using an HPLC system (P100-AS3000, Thermo Electron, Waltham, MA, USA) equipped with a Spectra Focus Diode Array Detector (UV3000, Spectra Physics Analytical, San Jose, CA, USA) set to $210 \mathrm{~nm}$. The analyses were performed isocratically at a flow rate of $0.8 \mathrm{~mL} / \mathrm{min}$ and with the column temperature set to $65^{\circ} \mathrm{C}$, with a $300 \times 7.8 \mathrm{~mm}$ i.d. Aminex HPX-87H cation exchange column and a cation $\mathrm{H}^{+}$ Microguard cartridge (Bio-Rad Laboratories, Hercules, CA, USA), using $0.0013 \mathrm{~mol} / \mathrm{L} \mathrm{H}_{2} \mathrm{SO}_{4}$ as mobile phase (Schneider et al., 1987). Data treatment was carried out using the ChromQuest $^{\mathrm{TM}}$ chromatography data system (ThermoQuest, San Jose, CA, USA).

\section{Phenolic composition}

The berry skins, in three replicates of 10 berries for each parcel, were removed manually from the pulp and dried with paper, then quickly immersed in $25 \mathrm{~mL}$ of a buffer solution containing $12 \% \mathrm{v} / \mathrm{v}$ ethanol, $600 \mathrm{mg} / \mathrm{L}$ sodium metabisulphite, $50 \mathrm{mg} / \mathrm{L} \mathrm{NaN}_{3}$ and $5 \mathrm{~g} / \mathrm{L}$ tartaric acid, and titrated to $\mathrm{pH} 3.20$ with the addition of $\mathrm{NaOH} 1 \mathrm{M}$ (Di Stefano \& Cravero, 1991). After homogenisation at $8000 \mathrm{rpm}$ for 1 min with a T25 Ultraturrax (IKA Labortechnik, Staufen, Germany), the extract was separated by centrifugation for 10 min in a PK 131 centrifuge (ALC International, MI, Italy) at $3000 \mathrm{rpm}$ and $20^{\circ} \mathrm{C}$. The supernatant was then used for analysis.

The seeds removed from the mesocarp were placed in 50 $\mathrm{mL}$ of the same buffer solution used for the skin extraction at $\mathrm{pH} 3.20$ and then kept for one week in a temperaturecontrolled room at $25^{\circ} \mathrm{C}$ (Di Stefano \& Cravero, 1991). The extract was then used for analysis.

The phenolic compounds of the berry skin and seed were determined by spectrophotometric methods (Torchio et al., 2010) using a UV-1601PC spectrophotometer (Shimazdu Scientific Instruments, Columbia, MD, USA). The total anthocyanin content was expressed as malvidin-3$O$-glucoside chloride, and the total flavonoid content of the skins and seeds was expressed as (+)-catechin. The relative standard deviations (RSD), based on repeated analysis $(\mathrm{n}=20)$ of the same sample, were $1.14 \%$ and $0.93 \%$ for total anthocyanin and total flavonoid content respectively (Torchio et al., 2010).

The analysis of individual anthocyanins was performed by HPLC-DAD after the application of the berry skin extract to a SEP-PAK C18 cartridge (Waters Corporation, Milford, MA, USA) and elution with methanol (Cagnasso et al., 2008). Chromatographic separation was carried out using a LiChroCart analytical column $(250 \mathrm{~mm} \times 4 \mathrm{~mm}$ i.d. $)$ 
purchased from Merck (Darmstadt, Germany), packed with LiChrosphere $100 \mathrm{RP}-18(5 \mu \mathrm{m})$ particles supplied by Alltech (Deerfield, IL, USA). Formic acid (10\% vol/vol) in water and formic acid $(10 \% \mathrm{vol} / \mathrm{vol})$ with methyl alcohol $(50 \%$ $\mathrm{vol} / \mathrm{vol}$ ) in water were used as mobile phases. The free forms of anthocyanins in the berry skin extracts were identified by comparison with external standards. The acylated forms of anthocyanins were identified by matching the DAD spectrum and retention time of each chromatographic peak, and by comparing these with published data (Pomar et al., 2005; Rolle \& Guidoni, 2007). Individual anthocyanin concentrations were determined by comparing the area of the appropriate peak against the total peak area; the data were expressed in percentages.

Determination of resveratrol was done according to the HPLC method described by Nicolosi Asmundo et al. (1999) using a DAD detector positioned to $310 \mathrm{~nm}$ and with a column Merck LiChrospher RP 100-18 (5 $\mu \mathrm{m})$ LiChroCart 250-4 thermostatically controlled at $30^{\circ} \mathrm{C}$. The analysis was performed isocratically at a flow rate of $0.5 \mathrm{~mL} / \mathrm{min}$. The mobile phase was water, acetic acid and acetonitrile at 75:5:20 ( $\mathrm{vol} / \mathrm{vol} / / \mathrm{vol})$. The quantification of resveratrol was achieved by area comparison with a external standard.

\section{Extractability index}

Phenol extractability indexes were assessed according to the procedure described by Saint-Criq et al. (1998), modified for Nebbiolo grapes studies (Cagnasso et al., 2008), using homogenised grapes with three replicates of 100 berries for each sample. The phenol extractability indexes were: cellular maturity index (EA\%) and seed maturity index (Mp\%) (Rio Segade et al., 2008; Gonzáles-Neves et al., 2010). The latter index was determined by taking into consideration the average ratio (TAR) between the total phenols (expressed as absorbance at $280 \mathrm{~nm}$ ) and the total anthocyanins of the skin (expressed as $\mathrm{g} / \mathrm{L}$ ) equal to 70 (Cagnasso et al., 2008). The $\mathrm{EA} \%$ and $\mathrm{Mp} \%$ indexes were calculated as follows:

$$
\begin{aligned}
& E A \%=\frac{(A 1-A 3.2)}{A 1} \times 100 \\
& M p \%=\frac{A 280-((A 3.2 / 1000) \times 70)}{A 280} \times 100
\end{aligned}
$$

where A1 and A3.2 were considered potential and extractible anthocyanin respectively (Saint-Criq et al., 1998).

\section{Texture analysis \\ Mechanical properties}

The tests were performed on the same day the berries were picked in order to avoid alterations. Before the test, the berries were arranged in a single layer and thermally conditioned in a thermostatically controlled chamber at $20^{\circ} \mathrm{C}$. A Universal Testing Machine TAxT2i Texture Analyser (Stable Micro Systems - SMS, Surrey, UK) equipped with an HDP/90 platform and a $5 \mathrm{~kg}$ load cell was used. Skin hardness was assessed with a puncture test using an SMS P2/N needle probe and a speed test of $1 \mathrm{~mm} / \mathrm{sec}$ (Letaief et al., 2008). Skin mechanical properties were evaluated with a puncture test to measure skin break force $(\mathrm{N})$, skin break energy $(\mathrm{mJ})$ and skin Young's Modulus (N/mm). Skin thickness ( $\mu \mathrm{m})$ was calculated as the distance between the point corresponding to probe contact with the berry skin (trigger) and the platform base during a compression test performed using a P2 flat probe and a speed test of $0.2 \mathrm{~mm} / \mathrm{sec}$ (Letaief et al., 2008).

For the Texture Profile Analysis (TPA) test, each whole berry was compressed in the equatorial position with an SMS $\mathrm{P} / 35$ flat probe, causing deformation of the berry to $25 \%$, with a waiting time between the two bites of two seconds using $1 \mathrm{~mm} \mathrm{~s}^{-1}$ as the speed test (Rio Segade et al., 2011). Typical texture parameters were determined and calculated by the software: hardness (N); cohesiveness (a-dimensional); gumminess $(\mathrm{N})$; springiness $(\mathrm{mm})$; chewiness $(\mathrm{mJ})$; and resilience (a-dimensional) (Rio Segade et al., 2011). Because they can be influenced by berry size, the first TPA parameters were also calculated as unitary values (norm.), i.e., the data were normalised to the respective berry diameter. All acquisitions were made at $400 \mathrm{~Hz}$; the data were evaluated using the Texture Expert Exceed software package (version 2.54 in Windows 2000).

\section{Statistical analysis}

The statistical analysis was performed using SAS statistical software (SAS Institute, Cary, NC, USA).

\section{RESULTS AND DISCUSSION \\ GFLV and GFkV mixed infection}

Although the GFLV symptoms on the leaves of the infected vines were rather limited, the field parameter values for vigour $(+19 \%)$ and yield $(+27 \%)$ of the healthy vines were statistically higher (Table 1), confirming previous findings that GFLV causes crop reductions from 20 to $90 \%$, depending on the cultivar and the environment of cultivation (Walter \& Martelli, 1996; Mannini, 2003). The berries of the healthy plants were greater in weight $(+7 \%)$ and diameter $(+5 \%)$ than those of the infected vines (Tables 1). Similar results from a previous field trial were observed after GFLV eradication from Nebbiolo vines (Mannini et al., 1998). The analysis of juice composition showed similar ripeness for the grapes harvested from the infected and the healthy vines (Table 2), despite the higher yield of the latter, confirming the results obtained by Mannini and collaborators on the same cultivar (Mannini, 2003). The amount of berry skin phenolic compounds was, on average, slightly higher in the infected vines. This was probably due to the lower yield, which might have beneficial effects on grape phenolic accumulation (Table 3). The extractability index (EA\%) was higher, however, indicating lower cell wall phenolic extractability; this might be related to the mechanical characteristics of the berries at harvest (Table 3 ).

TPA revealed differences in the values of the parameters between the healthy and the infected vines, with a different firmness of the whole berry depending on the plant's virological status (Table 4). This difference was particularly evident when the values were compared against the normalised data (i.e. referred to the respective berry diameters). The greatest differences were to be found in skin thickness, which was greater in the berries from the infected vines (Table 4). Berry skin thickness, together with skin break force, is an important technological parameter for red grapes, 
as it is related to the extractability of phenolic substances from the skin (Río Segade et al., 2011). Skin break force and thickness are directly related to the cell permeability index (EA\%) (Río Segade et al., 2008), from which information on the ease of transfer of these compounds can be gained. Briefly, the higher the EA\% values, the slower and less the dissolution of anthocyanins in the must during maceration (Cagnasso et al., 2008). In contrast, the extraction of anthocyanins from the harder skins of the Nebbiolo grapes is more complete but slower (Rolle et al., 2012).
The mixed infection with GFLV and GFkV appeared to alter the synthesis pathway of anthocyanins, interfering with their evolution. In the anthocyanin profile of the berry skin of grapes from the infected plants there was a higher percentage of instable di-substituted anthocyanidins (i.e., cyanidin peonidin-3-O-glucoside and peonidin-3-O-glucoside) and a lower percentage of tri-substituted malvidin-3-O-glucoside (Table 3). The sum of peonidin derivates was $6 \%$ higher in the infected plants than in the healthy ones, while the sum of malvidin derivatives was $5.4 \%$ lower.

TABLE 1

Field performances of healthy or virus-infected vines of 'Nebbiolo'

\begin{tabular}{lccccccccc}
\hline \multicolumn{1}{c}{ Data 2008 } & Healthy & GFLV & Sign & Healthy & GLRaV1+GVA & Sign & Healthy & GLRaV3+GVA Sign \\
\hline Yield (kg/vine) & $2.41 \pm 0.74$ & $1.76 \pm 0.62$ & $* *$ & $3.21 \pm 0.1$ & $2.44 \pm 0.9$ & $*$ & $3.09 \pm 0.9$ & $3.23 \pm 0.9$ & $\mathrm{~ns}$ \\
Bunch wt (g) & $352 \pm 51$ & $325 \pm 126$ & $\mathrm{~ns}$ & $352 \pm 66$ & $339 \pm 48$ & $\mathrm{~ns}$ & $357 \pm 52$ & $406 \pm 84$ & $*$ \\
Berry wt (g) & $1.59 \pm 0.07$ & $1.48 \pm 0.12$ & $* *$ & $1.95 \pm 0.09$ & $2.05 \pm 0.1$ & $* *$ & $1.93 \pm 0.09$ & $1.98 \pm 0.1$ & $\mathrm{~ns}$ \\
Berry diameter (mm) & $12.88 \pm 0.42$ & $12.30 \pm 0.66$ & $* * *$ & $13.42 \pm 1.03$ & $13.52 \pm 0.91$ & $\mathrm{~ns}$ & $13.13 \pm 1.03$ & $13.18 \pm 0.83$ & $\mathrm{~ns}$ \\
Pruning wood wt (g/vine) & $798 \pm 161$ & $648 \pm 172$ & $*$ & $1423 \pm 374$ & $1273 \pm 278$ & $\mathrm{~ns}$ & $1488 \pm 274$ & $1325 \pm 274$ & $\mathrm{~ns}$ \\
\hline
\end{tabular}

All data are expressed as average values \pm standard deviation $(\mathrm{n}=20)$. Significance: $*=\mathrm{p} \leq 0.05, * *=\mathrm{p} \leq 0.01, * * *=\mathrm{p} \leq$ $0.001, \mathrm{~ns}=$ not significant

TABLE 2

Juice chemical composition of healthy or virus-infected vines of 'Nebbiolo'

\begin{tabular}{lccccccccc}
\hline \multicolumn{1}{c}{ Data 2008 } & Healthy & GFLV & Sign & Healthy & GLRaV1+GVA & Sign & Healthy & GLRaV3+GVA & Sign \\
\hline Reducing sugars (g/L) & $230 \pm 0.58$ & $235 \pm 4.5$ & $\mathrm{~ns}$ & $225 \pm 1.5$ & $229 \pm 3.2$ & $\mathrm{~ns}$ & $231 \pm 4.6$ & $225 \pm 2.9$ & $\mathrm{~ns}$ \\
Titratable acidity (g/L) & $7.1 \pm 0.29$ & $6.8 \pm 0.1$ & $\mathrm{~ns}$ & $8.6 \pm 0.06$ & $8.8 \pm 0.10$ & $*$ & $8.3 \pm 0.5$ & $8.3 \pm 0.5$ & $\mathrm{~ns}$ \\
$\mathrm{pH}$ & $3.02 \pm 0.03$ & $3.06 \pm 0.02$ & $\mathrm{~ns}$ & $3.05 \pm 0.02$ & $3.07 \pm 0.01$ & $\mathrm{~ns}$ & $3.05 \pm$ & $3.08 \pm 0.03$ & $\mathrm{~ns}$ \\
Tartaric acid (g/L) & $6.03 \pm 0.45$ & $5.65 \pm 0.45$ & $\mathrm{~ns}$ & $5.99 \pm 0.26$ & $6.13 \pm 0.32$ & $\mathrm{~ns}$ & $6.18 \pm 0.6$ & $5.9 \pm 0.6$ & $\mathrm{~ns}$ \\
Malic acid (g/L) & $0.91 \pm 0.21$ & $0.85 \pm 0.26$ & $\mathrm{~ns}$ & $2.18 \pm 0.27$ & $2.30 \pm 0.24$ & $\mathrm{~ns}$ & $1.74 \pm 0.3$ & $2.01 \pm 0.3$ & $\mathrm{~ns}$ \\
\hline
\end{tabular}

All data are expressed as average values \pm standard deviation $(\mathrm{n}=20)$. Significance: $*=\mathrm{p} \leq 0.05, * *=\mathrm{p} \leq 0.01, * * *=\mathrm{p} \leq$ $0.001, \mathrm{~ns}=$ not significant.

TABLE 3

Grape phenolic composition, anthocyanin profiles and extractability indexes of healthy or virus-infected vines of 'Nebbiolo'

\begin{tabular}{|c|c|c|c|c|c|c|c|c|c|}
\hline & Healthy & GFLV & Sign & Healthy & GLRaV1+GVA & Sign & Healthy & GLRaV3+GVA & Sign \\
\hline EA \% & $58.2 \pm 0.6$ & $62.7 \pm 2.6$ & $*$ & $32.7 \pm 3.6$ & $37.9 \pm 3.6$ & ns & $39.5 \pm 9.9$ & $39.0 \pm 13.0$ & ns \\
\hline Mp \% & $41.5 \pm 5.9$ & $40.1 \pm 7.4$ & ns & $45.8 \pm 1.7$ & $45.6 \pm 2.4$ & ns & $40.7 \pm 6.0$ & $41.2 \pm 9.6$ & ns \\
\hline Seed total flavonoids ( $\mathrm{mg} / \mathrm{kg}$ berries) & $2656 \pm 130$ & $2691 \pm 236$ & ns & $2224 \pm 184$ & $2331 \pm 281$ & ns & $2246 \pm 77$ & $2163 \pm 190$ & $\mathrm{~ns}$ \\
\hline Skin total flavonoids ( $\mathrm{mg} / \mathrm{kg}$ berries) & $3970 \pm 151$ & $4146 \pm 200$ & ns & $2687 \pm 275$ & $2348 \pm 314$ & ns & $2816 \pm 265$ & $2605 \pm 302$ & ns \\
\hline Resveratrol (mg/kg berries) & nd & nd & - & $0.25 \pm 0.1$ & $0.52 \pm 0.14$ & $*$ & $0.33 \pm 0.0$ & $0.26 \pm 0.1$ & ns \\
\hline Total anthocyanins ( $\mathrm{mg} / \mathrm{kg}$ berries) & $688 \pm 27$ & $783 \pm 102$ & ns & $556 \pm 73$ & $551 \pm 40$ & ns & $604 \pm 65$ & $506 \pm 90$ & ns \\
\hline$\Sigma$ Simple glucosides $(\%)$ & $88.7 \pm 0.6$ & $89.6 \pm 0.4$ & ns & $91.4 \pm 0.8$ & $92.0 \pm 0.6$ & ns & $91.0 \pm 0.4$ & $89.2 \pm 1.9$ & ns \\
\hline$\Sigma$ Acetyglucoside anthocyanins (\%) & $4.4 \pm 0.2$ & $3.9 \pm 0.4$ & ns & $3.6 \pm 0.4$ & $3.6 \pm 0.7$ & ns & $3.6 \pm 0.2$ & $4.1 \pm 0.4$ & ns \\
\hline$\Sigma$ Cinnamoylglucoside anthocyanins (\%) & $7.0 \pm 0.5$ & $6.6 \pm 0.1$ & ns & $4.9 \pm 0.5$ & $4.6 \pm 0.3$ & ns & $5.3 \pm 0.2$ & $5.8 \pm 0.8$ & ns \\
\hline$\Sigma$ Delphinidin derivates $(\%)$ & $4.2 \pm 0.2$ & $3.6 \pm 1.0$ & ns & $6.4 \pm 0.6$ & $7.1 \pm 0.3$ & ns & $6.1 \pm 0.4$ & $5.5 \pm 0.9$ & ns \\
\hline$\Sigma$ Cyanidin derivates $(\%)$ & $15.1 \pm 1.4$ & $16.2 \pm 1.2$ & ns & $16.1 \pm 1.6$ & $22.9 \pm 1.9$ & $* *$ & $15.1 \pm 2.7$ & $13.8 \pm 0.5$ & $\mathrm{~ns}$ \\
\hline$\Sigma$ Petunidin derivates $(\%)$ & $5.4 \pm 0.4$ & $4.7 \pm 0.7$ & ns & $6.1 \pm 0.3$ & $5.6 \pm 0.4$ & ns & $6.0 \pm 0.3$ & $5.8 \pm 0.7$ & ns \\
\hline$\Sigma$ Peonidin derivates $(\%)$ & $50.5 \pm 1.1$ & $56.5 \pm 3.5$ & $*$ & $44.7 \pm 1.9$ & $44.4 \pm 3.4$ & $\mathrm{~ns}$ & $46.2 \pm 0.8$ & $45.0 \pm 3.6$ & ns \\
\hline$\Sigma$ Malvidin derivates $(\%)$ & $24.8 \pm 1.4$ & $19.4 \pm 1.8$ & $*$ & $26.6 \pm 3.0$ & $20.3 \pm 1.6$ & $*$ & $26.6 \pm 2.0$ & $29.0 \pm 1.4$ & ns \\
\hline
\end{tabular}

All data are expressed as average values \pm standard deviation $(\mathrm{n}=3)$. Significance: $*=\mathrm{p} \leq 0.05, * *=\mathrm{p} \leq 0.01, \mathrm{~ns}=\mathrm{not}$ significant. 
TABLE 4

Mechanical properties of healthy or virus-infected grapes 'Nebbiolo'

\begin{tabular}{|c|c|c|c|c|c|c|c|c|c|}
\hline Data 2008 & Healthy & GFLV & Sign & Healthy & GLRaV1+GVA & Sign & Healthy & GLRaV3+GVA & Sign \\
\hline Skin break force $(\mathrm{N})$ & $0.52 \pm 0.09$ & $0.51 \pm 0.10$ & ns & $0.52 \pm 0.13$ & $0.55 \pm 0.13$ & ns & $0.52 \pm 0.12$ & $0.56 \pm 0.10$ & ns \\
\hline Skin break energy $(\mathrm{mJ})$ & $0.31 \pm 0.11$ & $0.28 \pm 0.09$ & ns & $0.36 \pm 0.15$ & $0.40 \pm 0.14$ & ns & $0.40 \pm 0.16$ & $0.42 \pm 0.12$ & ns \\
\hline Young's Modulus (N/mm) & $0.42 \pm 0.07$ & $0.45 \pm 0.07$ & $*$ & $0.35 \pm 0.05$ & $0.36 \pm 0.06$ & ns & $0.32 \pm 0.05$ & 0.05 & ns \\
\hline Skin thickness $(\mu \mathrm{m})$ & $199 \pm 22$ & $217 \pm 24$ & $* *$ & $203 \pm 25$ & $199 \pm 29$ & ns & $195 \pm 31$ & $208 \pm 28.4$ & $*$ \\
\hline Berry hardness $(\mathrm{N})$ & $4.53 \pm 0.46$ & $4.68 \pm 0.56$ & ns & $4.91 \pm 0.77$ & $4.96 \pm 0.98$ & ns & $4.16 \pm 0.88$ & $4.53 \pm 0.74$ & ns \\
\hline Berry cohesiveness (-) & $0.73 \pm 0.02$ & $0.72 \pm 0.02$ & ns & $0.71 \pm 0.03$ & $0.73 \pm 0.04$ & * & $0.73 \pm 0.004$ & $0.73 \pm 0.03$ & ns \\
\hline Berry gumminess $(\mathrm{N})$ & $3.28 \pm 0.26$ & $3.35 \pm 0.36$ & ns & $3.45 \pm 0.45$ & $3.57 \pm 0.56$ & ns & $3.00 \pm 0.53$ & $3.30 \pm 0.48$ & * \\
\hline Berry springiness (mm) & $2.15 \pm 0.08$ & $2.04 \pm 0.11$ & $* * *$ & $2.20 \pm 0.17$ & $2.25 \pm 0.13$ & ns & $2.15 \pm 0.19$ & $2.17 \pm 0.16$ & ns \\
\hline Berry chewiness $(\mathrm{mJ})$ & $7.05 \pm 0.64$ & $6.86 \pm 0.98$ & ns & $7.62 \pm 1.36$ & $8.06 \pm 1.67$ & ns & $6.52 \pm 1.51$ & $7.16 \pm 1.37$ & ns \\
\hline Berry resilience (-) & $0.40 \pm 0.02$ & $0.40 \pm 0.02$ & ns & $0.37 \pm 0.02$ & $0.39 \pm 0.03$ & $*$ & $0.39 \pm 0.03$ & $0.39 \pm 0.03$ & ns \\
\hline Berry hardness ${ }_{\text {norm. }}$ & $0.35 \pm 0.04$ & $0.38 \pm 0.04$ & $* *$ & $0.37 \pm 0.05$ & $0.36 \pm 0.06$ & $\mathrm{~ns}$ & $0.32 \pm 0.05$ & $0.34 \pm 0.05$ & $*$ \\
\hline Berry gumminess ${ }_{\text {norm. }}$ & $0.25 \pm 0.02$ & $0.27 \pm 0.02$ & $* *$ & $0.26 \pm 0.03$ & $0.26 \pm 0.03$ & ns & $0.23 \pm 0.03$ & $0.25 \pm 0.03$ & $*$ \\
\hline Berry springiness ${ }_{\text {norm. }}$ & $0.17 \pm 0.002$ & $0.17 \pm 0.001$ & ns & $0.16 \pm 0.003$ & $0.17 \pm 0.003$ & $* *$ & $0.16 \pm 0.01$ & $0.16 \pm 0.005$ & ns \\
\hline Berry chewiness $_{\text {norm. }}$ & $0.04 \pm 0.004$ & $0.05 \pm 0.004$ & $* *$ & $0.04 \pm 0.005$ & $0.04 \pm 0.01$ & ns & $0.041 \pm 0.01$ & $0.037 \pm 0.01$ & * \\
\hline
\end{tabular}

All data are expressed as average values \pm standard deviation $(\mathrm{n}=30)$. Significance: $*=\mathrm{p} \leq 0.05, * *=\mathrm{p} \leq 0.01, \mathrm{~ns}=$ not significant.

\section{GLRaV-1 and GVA mixed infection}

The vines infected with GLRaV1 and GVA statistically produced a lower yield (-24\%) than the healthy vines, with lighter bunches and bigger berries on average (Table 1). Vegetative vigour, expressed as winter pruning wood weight, was also lower compared to the virus-free plants. Grape juice composition was fairly similar for the two sanitary statuses, although titratable acidity was slightly but significantly higher in the infected plants. These observations are in line with results from a previous experiment with the same phloematic viruses (GLRaV-1 and GVA): reduced vegetative growth and reduced canopy physiological efficiency, resulting in reduced crop yield but without affecting sugar content (Mannini \& Credi, 2000).

On average, the amount of phenolic compounds in the berry skin was higher in the healthy vines, but not as high as expected according to previous studies (Guidoni et al., 1997a; 1997b). The resveratrol content was much higher $(+48 \%)$ in the grapes from the infected vines (Table 3), confirming the hypothesis that the production of this compound could be a response to biotic stress (Barlass et al., 1987).

As observed with the GFLV and GFkV infection, GLRaV-1 and GVA mixed infection also seemed to interfere with the synthesis pathway of berry skin anthocyanins, as seen in profiles richer in less stable di-substituted cyanidin-3glucoside and poorer in tri-substituted malvidin-3-glucoside (Table 3).

There were few differences in mechanical berry characteristics between the two sanitary statuses (Table 4), and they were apparently irrelevant in terms of phenolic extractability (Table 3).

\section{GLRaV-3 and GVA mixed infection}

The yield response was fairly similar between the two progenies (Table 1), although leafroll symptoms clearly had appeared on the vines in mid-August. While vigour and the concentration of juice soluble solids was, on average, higher in the healthy grapevines, there was no substantial difference in yield between the two virological statuses, and the bunches were only slightly lighter in the virus-free plants (Table 1). In general, the viral impact observed in the present study was less than that reported by other studies, where, in one case, the eradication of a mixed infection with GLRaV-3 and GVA from a Nebbiolo clone led to better grape quality (Mannini \& Credi, 2000) and, in the other, GLRaV-3 infection in Merlot and Cabernet sauvignon cv. resulted in a considerable loss in production, soluble solids and total anthocyanin content (Borgo et al., 2003).

The amount of grape phenolic compounds, anthocyanins and flavonoids was slightly higher in the healthy plants, while the EA\% index values were quite similar, as previously described for grapevines infected with GLRaV-1 and GVA (Table 3). Alterations in the berry anthocyanin profile noted in that case were not confirmed, however.

The values for berry skin thickness of the grapes from the healthy vines were lower (Table 4). This parameter of berry mechanical properties is considered an efficient prediction index of anthocyanin extractability, and therefore holds special oeno-technological interest. In this sense, thinner skins seem to be characterised by a greater release of red pigments (Río Segade et al., 2011). This is particularly important for the grapes of the Nebbiolo cv., which is genetically poor in malvidin derivative forms, the anthocyanidins which chiefly contribute to creating the intensity and stability of wine colour.

Several differences were observed in the hardness, gumminess and chewiness of the whole berry, particularly when compared to normalised values. As these parameters are widely used as ripeness predictors in grape sensory analysis (Le Moigne et al., 2008), the differences between the infected and the healthy grapes, imputable to unequal pulp deliquescence, could make the interpretation of taste results difficult. 


\section{CONCLUSIONS}

Mixed infection in grapevines with GFLV and GFkV, GLRaV-1 and GVA, or GLRaV-3 and GVA can seriously affect crop quantity and quality in different ways, depending on the viruses involved. On average, all virus infections reduced grapevine vigour, particularly in the plants infected with GFLV and GFkV, while crop yield was reduced only in those grapevines infected with GFLV and GFkV and those with GLRaV-1 and GVA infection, but not those with GLRaV3 and GVA. In this case, juice soluble solids were slightly lower compared to healthy vines, while in the other two cases the reducing sugars were practically uninfluenced. Bunch and berry size were influenced differently by virological status. Smaller berries were found on the GFLVand GFkV-infected vines, while larger berries were produced by plants with GLRaV1 and GVA infection.

On average, the berry phenolic compounds were slightly lower in the leafroll-infected vines (both GLRaV-1 and GLRaV-3) than in the healthy plants, while the opposite was observed in the fanleaf-infected vines (GFLV). In this case, however, the dramatically reduced yield from the diseased vines could have had an effect on phenolic concentration.

Fanleaf (GFLV) and leafroll, but only when due to GLRaV-1, interfered with the synthesis pathway of grape anthocyanins, inducing an anthocyanin profile richer in instable di-substituted anthocyanins (i.e. cyanidin and peonidin-3-glucoside) and poorer in tri-substituted malvidin3-glucoside. These aspects may be of particular importance for cultivars like Nebbiolo, which have a berry anthocyanin profile genetically poorer in the more stable tri-substituted anthocyanins, making it difficult to achieve acceptable wine colour intensity and stability. Moreover, mixed infections with GFLV and GFkV, and GLRaV-3 and GVA induced a change in the mechanical properties of the berry skin, most evident in skin thickening, which decreased the phenol extractability in these berries.

Our results indicate that virus infection in grapevines may negatively affect these fundamental parameters of wine quality. Further studies are need to better understand the practical implications of these changes for winemaking and wine quality.

\section{LITERATURE CITED}

Barlass, M., Miller, R.M. \& Douglas, T.J., 1987. Development of methods for screening grapevines for resistance to infection by Downy Mildew. II. Resveratrol production. Am. J. Enol. Vitic. 38, 65-68.

Borgo, M., Angelini, E. \& Flamini, R., 2003. Effetti del virus GLRaV-3 dell'accartocciamento fogliare sulle produzioni di tre vitigni. L'Enologo 39 , 99-110.

Boscia, D., Greif, C., Gugerli, P., Martelli, G.P., Walter, B. \& Gonsalves, D., 1995. Nomenclature of grapevine leafroll-associated putative closteroviruses. Vitis 34, 171-175.

Cabaleiro, C., Segura, A. \& Garcia-Berrios, J.J., 1999. Effects of grapevine leafroll associated virus 3 on the physiology and must of Vitis vinifera L. cv Albariño following contamination in the field. Am. J. Enol. Vitic. 50, 40-44.

Cagnasso, E., Rolle, L., Caudana, A. \& Gerbi, V., 2008. Relations between grape phenolic maturity and red wine phenolic composition. Ital. J. Food Sci. 20, 365-380
Celotti, E. \& Carcereri De Prati, G., 2005. The phenolic quality of red grapes at delivery: objective evaluation with colour measurements. S. Afr. J. Enol. Vitic. 26, 75-82.

Credi, R. \& Babini, A.R., 1997. Effects of viruses and virus-like infections on growth, yield, fruit quality of Albana and Trebbiano Romagnolo grapevines. Am. J. Enol. Vitic., 48, 7-12.

De Beer, D., Joubert, E., Marais, J. \& Manley, M., 2006. Maceration before and during fermentation: effect on Pinotage wine phenolic composition, total antioxidant capacity and objective colour parameters. S. Afr. J. Enol. Vitic. 27, 137-150.

Di Stefano, R. \& Cravero, M.C., 1991. Metodi per lo studio dei polifenoli dell'uva. Riv. Vitic. Enol. 44, 37-45.

Gabler, F.M., Smilanick, J.L., Mansour, M., Ramming, W. \& Mackey, B.E., 2003. Correlations of morphological, anatomical and chemical features of grape berries with resistance to Botrytis cinerea. Phytopathology 93, 12631273

Gómez-Míguez, M. \& Heredia, F.J., 2004. Effect of the maceration technique on the relationships between anthocyanin composition and objective color of Syrah wines. J. Agric. Food Chem. 52, 5117-5123.

Gonzáles-Neves, G., Gil, G., Ferrer, M., Darwin, C., Balado, J., Bochicchio, R., Gatto, G. \& Tessore, A., 2010. Prediction of the colour and polyphenolic composition of the young red wines from the phenolic potential of the grapes. Int. J. Food Sci. Technol. 45, 1843-1851.

Guidoni, S., Mannini, F., Ferrandino, A., Argamante, N. \& Di Stefano, R., 1997a. The effect of grapevine leafroll and rugose wood sanitation on agronomic performance and berry and leaf phenolic content of a Nebbiolo clone (Vitis Vinifera L.). Am. J. Enol. Vitic. 48, 438-442.

Guidoni, S., Mannini, F., Ferrandino, A., Argamante, N. \& Di Stefano, R., 1997b. Effect of virus status on leaf and berry phenolic compounds in two wine grapevine Vitis vinifera cultivars. Acta Hort. 526, 445-452.

Kovacs, L.G., Hanami, H., Fortenberry, M. \& Kaps, M.L., 2001. Latent infection by leafroll agent GLRaV-3 is linked to lower fruit quality in French-American hybrid grapevine Vidal blanc and St. Vincent. Am. J. Enol. Vitic. 52, 254-259.

Lang, A. \& During, H., 1990. Grape berry splitting and some mechanical properties of the skin. Vitis 29, 61-70.

Le Moigne, M., Maury, C., Bertrand, D. \& Jourjon, F., 2008. Sensory and instrumental characterisation of Cabernet Franc grapes according to ripening stages and growing location. Food Qual. Pref. 19, 220-231.

Letaief, H., Rolle, L. \& Gerbi, V., 2008. Mechanical behavior of winegrapes under compression tests. Am. J. Enol. Vitic. 59, 323-329.

Mannini, F., 2003. Virus elimination in grapevine and crop performance Proc. $14^{\text {th }}$ Meeting of the International Council for the Study of Virus and Virus-Like Disease of the Grapevine (ICVG), September 2003, Locorotondo (BA), Italy, pp. 234-239 (www.icvg.ch/archive.htm).

Mannini, F., Argamante, N., Cuozzo, D. \& Credi, R., 2006. Modification in field behaviour and grape quality, with focus on terpenes, after GLRaV-3 eradication in a clone of white Muscat (Vitis vinifera L.). Proc. $15^{\text {th }}$ Meeting of the International Council for the Study of Virus and Virus-Like Disease of the Grapevine (ICVG), April 2006, Stellenbosch (SA), pp. 136-138 (www.icvg.ch/archive.htm)

Mannini, F., Argamante, N. \& Credi, R., 1999. Contribution of virus infection to clonal variability of some Vitis vinifera L. cultivars. Bulletin OIV, 72, 145-160.

Mannini, F. \& Credi, R., 2000. Appraisal and enological modifications in the performances of grapevine clones after virus eradication. Proc. $13^{\text {th }}$ Meeting of the International Council for the Study of Virus and Virus-Like Disease of the Grapevine (ICVG), March 2000, Adelaide (AUS). pp. 151154 (www.icvg.ch/archive.htm). 
Mannini, F., Gerbi, V. \& Credi, R., 1998. Heat-treated v. virus-infected grapevine clones: agronomical and enological modifications. Acta Hort. $473,155-163$.

Martelli, G.P., 1993 (ed.). Graft-transmissible disease of grapevines. Handbook for detection and diagnosis. FAO Publication Division, Rome.

Nicolosi Asmundo, C., Muratore, G., Cataldi Lupo, M.C. \& Campisi, S., 1999. Il contenuto di resveratrolo in alcuni vini rossi di Sicilia. Vignevini, $26,105-108$

O.I.V., 2008. Recueil international des méthodes d'analyse des vins et des moûts. Paris, France.

Ortega-Regules, A., Romero-Cascales, I., Ros-García, J.M., López-Roca, J.M. \& Gómez-Plaza, E., 2006. A first approach towards the relationship between grape skin cell-wall composition and anthocyanin extractability. Anal. Chim. Acta 563, 26-32.

Pomar, F., Novo, M. \& Masa, A., 2005. Varietal differences among the anthocyanin profiles of 50 red table grape cultivars studied by high performance liquid chromatography. J. Chrom. A. 1094, 34-41.

Río Segade, S., Giacosa S., Gerbi, V. \& Rolle, L., 2011. Berry skin thickness as main texture parameter to predict anthocyanin extractability in winegrapes. LWT - Food Sci. Technol., 44, 392-398.

Río Segade, S., Rolle, L., Gerbi, V. \& Orriols, I., 2008. Phenolic ripeness assessment of grape skin by texture analysis. J. Food Comp. Anal. 21, 644649

Río Segade, S., Orriols, I., Giacosa, S. \& Rolle, L., 2011. Instrumental texture analysis parameters as winegrapes varietal markers and ripeness predictors. Int. J. Food Prop. 14, 1318-1329.

Rolle, L. \& Guidoni, S., 2007. Color and anthocyanin evaluation of red winegrapes by CIE L*, a*, b* parameters. J. Int. Sci. Vigne Vin 41, 193-201.

Rolle, L., Torchio, F., Zeppa, G. \& Gerbi, V., 2008. Anthocyanin extractability assessment of grape skins by texture analysis. J. Int. Sci. Vigne Vin 42, 157-162.
Rolle, L., Torchio, F., Zeppa, G. \& Gerbi, V., 2009. Relationship between skin break force and anthocyanin extractability at different ripening stages. Am. J. Enol. Vitic. 60, 1, 93-97.

Rolle, L., Torchio, F., Ferrandino, A. \& Guidoni, S., 2012. Influence of wine-grape skin hardness on the kinetics of anthocyanin extraction. Int. J. Food Prop., in press, DOI: 10.1080/10942911003778022.

Sacchi, K.L., Bisson, L.F. \& Adams, D.O., 2005. A review of the effect of winemaking techniques on phenolic extraction in red wines. Am. J. Enol. Vitic. 56, 197-206.

Saint-Criq, N., Vivas, N. \& Glories, Y., 1998. Maturité phénolique: définition et contrôle. Rev. Fr. Oenol. 173, 22-25.

Schneider, A., Gerbi, V. \& Redoglia, M., 1987. A rapid HPLC method for separation and determination of major organic acids in grape musts and wines. Am. J. Enol. Vitic. 38, 151-155.

Torchio, F., Cagnasso, E., Gerbi, V. \& Rolle, L., 2010. Mechanical properties, phenolic composition and extractability indices of Barbera grapes of different soluble solids contents from several growing areas. Anal. Chim. Acta 660, 183-189.

Vidal, S., Francis, L., Noble, A., Kwiatkowski, M., Cheynier, V. \& Waters, E., 2004. Taste and mouth-feel properties of different types of tannin-like polyphenolic compounds and anthocyanins in wine. Anal. Chim. Acta 513, $57-65$

Walter, B. \& Martelli, G.P., 1996. Sélection sanitaire et sélection pomologique. Influence des viroses et qualitè: effect des viroses sur la culture de la vigne et ses produits. Bulletin O.I.V. 70, 5-23.

Zanoni, B., Siliani, S., Canuti, V., Rosi, I. \& Bertuccioli, M., 2010. A kinetic study on extraction and transformation phenomena of phenolic compounds during red wine fermentation. Int. J. Food Sci. Technol. 45, 2080-2088.

Zouid, I., Siret, R., Mehinagic, E., Maury, C., Chevalier, M. \& Jourjon, F., 2010. Evolution of grape berries during ripening: investigations into the links between their mechanical properties and the extractability of their skin anthocyanins. J. Int. Sci. Vigne Vin 44, 87-99. 